\title{
Onko uralilaisen etnohistorian tutkimuksessa tapahtunut käänne? Monitieteisyys ja uudet teoriat itämerensuomalaisten kielten synnystä Valter Langin Homo Fennicuksen valossa
}

\author{
Janne Saarikivi \\ University of Helsinki, Finland \\ janne.saarikivi@helsinki.fi
}

\begin{abstract}
Abstrakti. The question of how linguistic and archaeological data can be combined to create a comprehensive account of the prehistory of present ethnicities is an intensely debated issue around the globe. In particular, identifying new language groups based on the material remnants of a particular area or discerning correlates in the material culture for the language contact periods reflected in loan word layers are complex and often probably insolvable questions. When it comes to the early history of the Finns and related peoples, Valter Lang's new monograph on the archaeology of Estonia and the "arrivals of the Finnic people" (Läänemeresoome tulemised, 2018) has been considered a paradigm-changing work in this respect. In this article, I argue that despite the undisputed progress made in this oeuvre, many of the old questions regarding time, place and method still remain.
\end{abstract}

Asiasanat: itämerensuomalaiset kielet, kantasuomi, arkeologia, germaaniset lainasanat, kantagermaani, pronssikausi, rautakausi, keramiikka, hiidenkiukaat, tarhakalmistot

\section{$1 \quad$ Ensiksikin}

Haluan onnitella Jack Rueteria, tutkijaa, fennougristia ja maailmankansalaista, suomalaisen fennougristisen yhteisön tärkeää jäsentä yhä kypsemmän iän ja arvovallan virstanpylvään saavuttamisen johdosta 23.3. 2021.

\section{Toiseksi, kysymys}

2000-luvulla on uralilaisia kieliä puhuvien kansojen etnistä esihistoriaa koskevien tutkimusten määrä huomattavasti kasvanut. Eräänä keskeisenä kysymyksenä on jatkuvasti eri tieteiden aineistojen yhteensovittaminen. Tämän esseen aiheena on kielen leviäminen suhteessa materiaaliseen kulttuurin, erityisesti liittyen Valter Langin esittämiin näkemyksiin itämerensuomalaisten kielten leviämisestä. Alun perin viroksi 
vuonna 2018 ilmestynyttä Läänemeresoome tulemised-teosta (Lang 2018) on referoitu sekä mediassa (mm. Ylen Aristoteleen kantapää 9.9. 2020 ja Ykkösaamu 11.9. 2020, MTV:n uutiset 10.9. 2020), että tutkimusjulkaisuissa (esim. Grünthal 2018). Teoksen uutta suomenkielistä laitosta Homo Fennicus (Lang 2020) on mainostettu jopa "käänteentekeväksi" (teoksen takakannessa).

Tarkastelen seuraavassa Langin esittämiä näkemyksiä itämerensuomalaisten ja muiden uralilaisten kansojen muotoutumisesta ja kysyn, missä määrin itämerensuomalaisten etnogeneesin tutkimuksessa on tapahtunut käänne. Huomioni kohteena ovat erityisesti metodit ja ajoitukset, eli kielitieteen ja arkeologian aineistojen yhdistäminen sekä kysymys siitä, mihin aikatasoon itämerensuomen muotoutuminen ja kontaktit tulee sijoittaa.

\section{Jatkuvuus, kritiikki ja uusi teoria}

Etnogeneesin tutkimus oli pitkään sidoksissa ajatukseen, jonka mukaan niin sanotut arkeologiset kulttuurit voidaan identifioida kielellisesti. Alunperin tämä käsitys syntyi mm. Gustaf Kossinnan ja Gordon W. Childen töissä 1900-luvun alussa. Uralistiikkaan se levisi monessa eri vaiheessa, ensin Hackmanin ns. maahanmuuttoteorian myötä 1900-luvun alussa ja sittemmin ns. jatkuvuusteoriana.

1900-luvun alkupuolella vallalla ollut teoria katsoi itämerensuomalaisen kielimuodon levinneen Suomeen Virosta (Hackman 1905). Sen mukaan leviäminen on yhteydessä rautakautisiin hautaustapojen muutoksiin. 1980-luvulla vakiintuneen jatkuvuusteorian mukaan (SVEJ 1984) suomalais-ugrilainen kantakieli levisi Suomeen ja Viroon jo kivikaudella ns. tyypillisen kampakeramiikan myötä, minkä jälkeen nykyisellä itämerensuomalaisella alueella ei kielenvaihtoja tapahtunut. Jatkuvuusteoriasta on esitetty erilaisia, toisistaan eroavia versioita, joista eräissä itämerensuomalainen alue uralilaistuu tekstiilikeramiikan ja siihen liittyvien keraamisten ryhmien myötä (Carpelan \& Parpola 2002), toisissa jo jääkauden jälkeen (Wiik 2002). Muitakin malleja on esitetty. Kaikille niistä yhteinen on näkemys, jonka mukaan sekä itämerensuomalaiset että saamelaiskielet ovat kehittyneet lähes uralilaisen kantakielen tasosta nykykieliksi nykyalueellaan tai sen lähistöllä.

2000-luvun alusta alkaen on jatkuvuusteorian argumentteja kritisoitu eri näkökulmista. Kielitieteen piiristä on esitetty $\mathrm{mm}$. seuraavia argumentteja (esim. Aikio \& Aikio 2001, Janhunen 2007):

1. lainasanakerrostumien liian vanhat ajoitukset; esim. balttilaiset ja germaaniset kontaktit on viety aikaan, jolloin germaanisia ja balttilaisia kieliä ei nykykäsityksen mukaan ole ollut olemassa

2. areaalilingvistinen argumentti; itämerensuomalaisten kielten keskinäiset erot vaikuttavat siltä, että niiden yhteisen kantakielen hajoaminen on vain n. 2000 vuotta vanha ilmiö

3. substraatti; jatkuvuusteorian ajoitukset eivät sovi myöhäiseltä vaikuttavaan saamelaiseen paikannimisubstraattiin suurimmassa osassa Suomea tai vielä myöhäisemmältä vaikuttavaan pohjoisfennoskandiseen (paleoeurooppalaiseen) substraattiin saamessa (esim. Aikio 2012) 
4. analogiat dokumentoiduista kielialueiden muutoksista; tavallisesti eurooppalaisessa kontekstissa kunkin alueen kielikartta on pikemminkin muutamia satoja kuin muutamia tuhansia vuosia vanha

Kielitieteen ja muiden tieteiden rajapinnalta on esitetty $\mathrm{mm}$. seuraavia kriittisiä huomioita (vrt. Saarikivi \& Lavento 2012):

1. hypoteesi kielialueiden ja arkeologisten alueiden vastaavuudesta on epätarkka ja voidaan monissa tapauksissa osoittaa vääräksi, esim.

a. keramiikan avulla määritellyt alueet ovat usein laajempia kuin kielialueet

b. kirveet ja muut käyttöesineet, metalliesineet ja niiden tyypit leviävät yleensä vaihdanta- ja kauppaverkostoissa, jotka ovat monikielisiä; niitä ei kielellisessä aineistossa vastaa kielen vaan sanaston leviäminen

c. hautaustavat ym. leviävät uusien uskonnollisten tapojen myötä pikemminkin kuin migraatioiden ja kielenvaihtojen; näihinkin liittyy usein pikemminkin sanaston kuin kokonaisen kielen leviäminen

2. tutkimuskirjallisuudessa mainitut arkeologiset kulttuurit ovat hyvin heterogeenisiä, ja monissa tapauksissa eivät ole verrattavissa toisiinsa samanarvoisina kokonaisuuksina

Vaikka jatkuvuusteorian puutteet on laajasti tunnustettu, ei yhtenäistä uutta teoriaa itämerensuomalaisten kielten taustasta ole ennen Langia esitetty. Nyt hän siirtää monia jatkuvuusteorian ajoituksia aikaisempaa selvästi myöhemmiksi ja pyrkii tarjoamaan kokonaisesityksen itämerensuomen muotoutumisesta.

Langin teorian pääkohdat ovat seuraavat:

1. Viron alue on itämerensuomalaistunut useassa aallossa, jotka liittyvät idästä saapuneisiin migraatioihin; ensimmäiset aallot ovat pronssikautisia ja saapuneet alueelle n. $1200 \mathrm{eKr}$.

2. Uusi väestö saapui Daugavan vesistöä pitkin idästä Baltiaan; tämä väestö toi mukanaan uuden keramiikan ja uralilaisen kielen

3. Suomen pronssikautiset hiidenkiukaat ja Viron kiviarkkukalmistot ovat germaanisen väestön jälkeensä jättämiä; tämä on asunut Itämeren piirissä ennen itämerensuomalaisia ja jättänyt jälkeensä "paleogermaanisia" lainoja (termistä Kallio 2012)

4. Rautakaudella tapahtui Pohjois-Viron alueen "lopullinen" itämerensuomalaistuminen, joka ilmenee Viron pohjoisrannikon tarhakalmistokulttuurissa. Tämä on noin 1200-1700 vuotta ensimmäistä itämerensuomalaistumista nuorempi ilmiö

Lang pohtii arkeologisen aineiston ja kielen välisiä suhteita ja näyttää suhtautuvan kriittisesti moniin aikaisempiin yrityksiin yhdistää kielitieteen ja arkeologian aineistoja. Toisaalta hänen johtopäätöksensä ovat silti varsin konservatiivisia erityisesti metodiikan näkökulmasta. Samoin kuin Carpelan (2008), myös Lang yhdistää yleensä keramiikan ja kielen. Myös hänen ajoituksensa Itämeren piirin uralilaistumiselle ja germaanis-itämerensuomalaisten kontaktien alkamiselle (n. 1200 eKr.) ovat edelleen niin vanhoja, että niitä on hankala yhdistää germanistiikan valtavirran ajoituksiin ja paikannuksiin. 
Tarkastelen seuraavassa näitä metodin, ajoituksen ja paikannuksen kysymyksiä hieman tarkemmin.

\section{$4 \quad$ Keramiikan ja kielen suhde}

Olemassa oleva tutkimuskirjallisuus ei vaikuta ainakaan kovin yksiselitteisesti tukevan otaksumaa, jonka mukaan keramiikkatyypit leviävät samalla tavoin kuin kielet. Sekä Carpelanin että Langin mainitsema oletus, jonka mukaan keramiikkaa ovat monissa esihistoriallisissa yhteisöissä tehneet lähinnä naiset saattaa hyvinkin pitää paikkansa. Sen sijaan oletus, että ihmiset olisivat oppineet kieliä lähinnä äideiltään tai perheissään saattaa olla liian yksinkertainen. Tavallisempaa on, että ihmiset oppivat ja käyttävät useita eri kieliä eri ikävaiheissa ja ympäristönsä erilaisiin sosiaalisiin verkostoihin liittyen. Vahvasti yksikieliset suuret yhteisöt, joissa ihminen puhuu koko ikänsä lähinnä vanhemmiltaan oppimaansa kieltä näyttävät liittyvän pikemminkin ihmiskunnan uudehkoihin kehitysvaiheisiin kuten paikallaan pysyvän maatalousyhteisön syntyyn. Metsästäjä-keräilijäyhteisöt taas ovat olleet pieniä ja usein monikielisiä sekä kieliidentiteetiltään joustavia (vrt. esim. Janhunen 1997).

Gosselain (2000) on tutkinut keramiikkatyyppien korrelaatioita kielen ja etnisiteetin kanssa afrikkalaisessa kontekstissa. Hän havaitsi, että keramiikan valmistamisessa on monia erilaisia vaiheita, joista esimerkiksi koristeaiheet liikkuvat helposti kielirajojen ja etnisiteetin rajojen yli. Toisaalta hän arvelee, että astian muotoilu on enemmän sidoksissa lähiyhteisössä tapahtuvaan oppimiseen. Gosselain osoittaa, miten KeskiAfrikan kontekstissa ei nykytasolla ole havaittavissa kielen ja keramiikkatyyppien välistä korrelaatiota, vaikka arveleekin, että eräät valmistusprosessin käytänteet ovat mahdollisesti levinneet bantuekspansion myötä. Kokonaiskuva on moninainen: eräät nykyisin bantukieliä käyttävät ryhmät ovat jatkaneet vanhoja paikallisia keraamisia traditioita, ja (mahdollisesti) bantujen myötä levinneitä keramiikkatraditioita taas jatkavat muihinkin kielikuntiin kuuluvia kieliä puhuvat kansat.

Vastaavia kielellisen ja materiaalisen kulttuurin epäsymmetrisiä limittymisiä on austronesialaisten ja papulaisten kielten alueella kuvannut mm. Terrell (2001). Hänen tutkimallaan Papuan pohjoisrannikolla useimmat väestöt ovat monikielisiä ja jakavat pitkälti samanlaisen materiaalisen kulttuurin. Alueella käytetään silti ryhmien sisäisessä kommunikaatiossa monia eri kieliä eikä materiaalisen kulttuurin yhdenmukaistuminen ole levittänyt minkäänlaista yleiskieltä, lingua francaa.

Hieman epäselväksi jääkin, miksi tulisi olettaa, että keramiikkatyyppien korrelaatio kielen kanssa olisi itämerensuomalaisella historiallisella kulttuurialueella ja pronssikaudella vahvempi kuin esimerkiksi 1900-luvun Kongossa tai Papualla. Tähän kysymykseen ei Langkaan tarjoa vastausta.

Vastaavankaltainen ongelma liittyy esimerkiksi pronssikautisiin hautaustapoihin, joissa Lang näkee läntistä germaanista vaikutusta. Hiidenkiukaat ja kiviarkkukalmistot voivat hyvinkin olla samanlaisia molemmin puolin Itämerta, samoin niistä tavattavassa dna:ssa voi olla yhtäläisyyksiä, mutta tämä ei vielä oikeuttane tekemään kovin suoraviivaisia johtopäätöksiä hautaustapoja käyttäneiden väestöjen kielestä. Uskonnollisia käytänteitä on voinut levitä Itämeren ylitse vaihdantaverkostoissa, ja tämä on voinut 
johtaa hautaustapojen muutokseen samaan tapaan kuin kristinuskon saapuessa tapahtui noin 1700 vuotta myöhemmin. Toisaalta meren yli siirtynyt väestö on voinut säilyttää uskontonsa ja hautaustapansa, mutta vaihtaa kielensä nopeasti. Esim. Haspelmathin ja Tadmorin lainasanoja koskevassa tutkimuksessa juuri uskonnollisen käsitteistön on todettu olevan kaikista tutkituista semanttisista kentistä herkimmin kielestä toiseen lainautuvaa (Haspelmath \& Tadmor 2009). Tämä osoittaa, että uskonnolliseen muutokseen liittyy monissa konteksteissa pikemminkin kulttuurin ja sanaston muutos kuin kokonaisen kielen leviäminen. Tämä näyttää olevan tilanne myös suurimmassa osassa Eurooppaa sekä kristinuskon että islamin levitessä.

\section{$5 \quad$ Moninaiset tulemiset}

Lang ajattelee itämerensuomalaisen kielimuodon saapuneen itämeren alueelle useina aaltoina pronssi- ja rautakauden välissä. Kullakin näistä kielellisistä aalloista on arkeologinen vastineensa (esim. Lang 2020: 245). Pääasialliset siirtymät ovat tapahtuneet pronssikaudella n. $1200 \mathrm{eKr}$. ja rautakaudella toista tuhatta vuotta myöhemmin.

Paleolingvistisen sanastomateriaalin näkökulmasta kantasuomi on kuitenkin yksiselitteisesti rautakautinen kieli. On selvä, että kantauralin ja kantasuomen välillä on jopa vuosituhansien kehitys - mahdollisesti noin 2000-2500 vuotta - mutta tätä kehitystä ei ole mahdollista kytkeä mihinkään selvään kantakielivaiheeseen. Siinä, missä kantasuomea erottaa kantauralista esimerkiksi yli 30 äänteellistä innovaatiota, uuden sijajärjestelmän synty ja kaksi suurta lainasanakerrostumaa - balttilainen ja germaaninen - ei mikään länsiuralilainen kielimuoto (esimerkiksi itämerensuomen ja saamen tai itämerensuomen, saamen ja mordvan hypoteettinen yhteinen kantamuoto) voi sisältää kuin muutamia äänteenmuutoksia.

Kantasuomen historia on tietenkin pitkä, ja siihen kuuluu pitkä "keskikantasuomalainen" kausi, jolloin itämerensuomalaiset äänteenmuutokset tapahtuvat ja balttilaiset ja germaaniset lainasanat omaksutaan (esim. Kallio 2007). Keskikantasuomalainen kieli ei kuitenkaan ole samassa mielessä yhdistettävissä ihmisyhteisöön kuin myöhäiskantasuomalainen kieli, joka edustaa uusinta hajoamattoman kantakielen rekonstruktiotasoa. Tällä kielimuodolla on täytynyt olla suhteellisen kompakti alue, ja näin on varmaan ollut myös sen edeltäjien laita. Toisaalta yli 1000 vuoden kielellisen historian aikana väestöt, jotka ovat käyttäneet kantasuomea, ovat voineet siirtyä tai vaihtuakin. Vaikka tunnemme kielen historian, emme oikeastaan tunne sitä puhuneen yhteisön historiaa siinä mielessä, että tuntisimme sosiaaliset voimat, jotka ovat saaneet ihmiset jatkamaan uralilaisen kielimuodon käyttöä uusien kulttuurivaikutteiden paineessa. On hyvin mahdollista, että osa varhaisesta keskikantasuomalaisesta yhteisöstä on assimiloitunut toisiin kieliyhteisöihin ja uralilainen kielimuoto säilynyt vain pienessä osassa aikaisempaa yhteisöä. Kun arkeologisessa aineistossa on laajalla alueella eriasteisia vaikutuksia niin idästä kuin lännestä, ei ole helppoa tai ehkä mahdollistakaan identifioida yhtä kompaktia arkeologisesti määrittyvää kontaktialuetta. Kielen näkökulmasta on täysin mahdollista, että eri-ikäiset kontaktit esim. germaanisiin kieliin ovat tapahtuneet eri alueilla. 
Jos Pohjois-Viro on uralilaistunut noin 3200 vuotta sitten, kuten Lang olettaa, on myös vaikeasti selitettävissä, miksi tämän varhaisen uralilaistumisen kielelliset jäljet ovat kokonaan hävinneet. Tilannetta voi verrata esim. kreikkaan, jonka kielialueen eräissä osissa kielellinen jatkuvuus on yli 3000 vuotta (esim. Horrocks 2010). Kreikan varhaisten jakautumisten myötä syntyneet "murre-erot" ovatkin varsin suuret ja monia kreikan periferisia murteita tulisikin kaiketi pitää lähinnä itsenäisinä kielinä. Sen sijaan pohjoisvirossa puhutaan melko yhtenäistä kielimuotoa, joskin vatjan kieli ja Kodaveren kielimuoto on mahdollista tulkita varhaisempien kielellisten ekspansioiden jäänteiksi. Näidenkin heijastamien kielellisten jakautumisten täytyy silti olla huomattavasti 3000 vuotta nuorempia - todennäköisesti rautakautisia eli myöhäiskantasuomen hajoamiseen perustuvia.

Lang olettaa, että itämerensuomen "toinen tuleminen" rautakaudella on pyyhkinyt altaan ensimmäisen tulemisen jäljet. Mutta jos näin on, mikä silloin on kielellinen todiste ensimmäisestä tulemisesta? Tällaiseksi kelpaavat Langille varhaiset "paleogermaaniset" lainat, eli sanat jotka näyttävät siltä, että ne on omaksuttu itämerensuomeen äännetasosta ennen varsinaista kantagermaania (vrt. Kallio 2012: 228-230). Tällaisia lainoja on todella esitetty $\mathrm{mm}$. Jorma Koivulehdon töissä, mutta niiden määrä on vähäinen ja koko kerrostuman olemassaoloa ei voi pitää täysin varmana. Toisaalta vaikka kerrostuma olisikin olemassa, on epäselvää, mikä on kielellinen peruste kytkeä se juuri Viron rannikon pronssikauteen (arkeologisia perusteita Lang toki esittää).

Epäselväksi jää sekin, miten paleogermaaniset sanat olisivat säilyneet kun oletettu kielenvaihto "ensimmäisen tulemisen" uralilaisesta kielestä "toisen tulemisen" kieleen on tapahtunut. Langin itsensäkin mukaan ensimmäisen ja toisen tulemisen kielten ero on todennäköisesti ymmärryskynnyksen ylittävä - mikä siis selittäisi sanaston säilymisen uuden kielellisen ekspansion pyyhkiessä altaan aiemman uralilaistumisen jäljet?

\section{Germaanikontaktien ajoitus - ratkaistu vai avoin ongelma?}

Kuten aikaisemmatkin tutkijat, myös Lang ajattelee, että germaaniset lainasanat on omaksuttu itämerensuomalaisiin kieliin niiden nykyisellä puhuma-alueella. Uutena voidaan pitää olettamaa, jonka mukaan kaikkein varhaisimmat germaaniset kontaktit ovat itse asiassa substraattia ns. tarhakalmistojen ajalta jolloin itämerensuomalaisten esi-isät omaksuivat germaanien elintapoja.

Kuten aikaisemmatkin yritykset paikantaa germaanikontakteja esim. skandinaavisen pronssikauden kontakteihin Suomessa (Carpelan \& Parpola 2002), ovat Langin ajoitukset varsin varhaisia. Germanistiikassa ajatellaan yleisimmin germaanien kielellisen alkukodin sijainneen ns. Jastorf-kulttuurin alueella Pohjois-Saksassa ja Tanskassa aikaisintaan n. $700 \mathrm{eKr}$ (ks. esim. Mallory 1988). Ringe (2006) pitää Jastorfiakin liian vanhana kielitieteen kannalta. Mm. Jorma Koivulehto on tosin esittänyt, että germaanisen alkukodin on täytynyt ulottua paljon kauemmaksi pohjoiseen (Koivulehto 2016), mutta Koivulehdon ajatukset eivät liene Suomen ulkopuolella kovinkaan laajasti hyväksyttyjä. 
Samaan tapaan kuin Viron ja kantasuomen leviämisen kohdalla, myöskään Ruotsin areaalilingvistiikassa monikaan seikka ei viittaa germaanisen kielimuodon varhaiseen ikään nyky-Ruotsin alueella. Esimerkiksi yleisesti arkaaisimpina skandinaavisena kielimuotona Ruotsissa pidetty älvdalska on kehittynyt itsenäisesti mahdollisesti vain noin 700-800 vuotta - ja sekin eroaa nykyruotsista pikemminkin kielen kuin murteen veroisesti (Kroonen 2016). Yli 3000 vuoden mittaisen germaanisen jatkuvuuden olettaisi heijastuvan huomattavasti suurempana ruotsin sisäisenä variaationa oikeastaan syvien kielierojen suuruisena. Mikäli kieliero olisi jonkin myöhemmin kielellisen ekspansion myötä pyyhkiytynyt pois, olettaisi vähintäänkin hyvin vanhakantaisen germaanisen nimistön kerrostumaa nyky-Ruotsin ydinalueella. Samankaltaisen olettaisi toki löytävänsä myös itämerensuomen ja germaanin kontaktialueella Virossa tai Suomessa, mikäli alueelle on germaaneja asettunut. Muutamat yritykset osoittaa Suomesta vanhoja germaanisia nimiä (Eura, Hauho ym., vrt. Koivulehto 1987) ovat toistaiseksi varsin spekulatiivisia, joskin asiaa lienee mahdollista tutkia tulevaisuudessa lisää. Kohtuullisen varmana voi käsittääkseni pitää ainoastaan eräiden vanhojen germaanisten henkilönimityyppien esiintymistä Suomen paikannimistössä (Harjavalta), mutta nämä eivät todista germaania puhuvasta väestöstä yhtään enempää kuin esimerkiksi ortodoksiset kristilliset nimityypit ItäSuomessa todistavat venäjänkielisestä väestöstä. Viron osalta koko kysymys lienee vielä selvittämättä.

Jos germaanikontaktit todella halutaan viedä yli 3000 vuoden taakse, ajaudutaan myös germaanisella taholla ainakin kahden "tulemisen" ongelmaan. Nykyiset germaaniset kielimuodot ovat olleet verrattain läheisiä vielä niiden alle 1500-vuotisen kirjoitetun historian aikana eivätkä esimerkiksi ruotsin ja saksan väliset erot viitanne yli 3000 vuoden erilliskehitykseen. Täytyisikin siis olettaa, että myös germaanista kieltä olisi levinnyt nyky-Ruotsiin ja Itämeren itärannalle useaan otteeseen. Skandinaavisen pronssikauden yleinen kulttuurikuva on kyllä melko indoeurooppalainen, mutta on hieman eri kysymys, edustaako se varsinaista germaanista väestöä vai jotakin kadonnutta kieliryhmää.

Paleolingvistiikan näkökulmasta germaaninen ja itämerensuomalainen kantakieli ovat monella tavoin samanlaisia. Molemmat väestöt ovat eläneet kyläyhteisöissä ja rakentaneet linnoitettuja asuinpaikkoja, harjoittaneet merenkulkua ja metallurgiaa kuten raudan valmistusta, viljelleet maata, pitäneet monenlaisia kotieläimiä ja nimittäneet päälliköitään kuninkaiksi. Kun nyt oletetulta suomalais-germaaniselta kontaktialueelta löytyy arkeologisia jäänteitä tällaisista kulttuurimuodoista, lienee vaikeaa erottaa kantagermaanista ja kantasuomalaista asutusta toisistaan. Kohtuullinen hypoteesi voisi olla, että saman asutuksen piirissä on usein asunut molempien kielten taitajia.

On huomautettava vielä siitäkin mahdollisuudesta, että osa itämerensuomen ja germaanin yhteisestä sanastosta saattaa olla peräisin myös jostain kolmannesta lähteestä. Toisin kuin monissa muissa indoeurooppalaisissa kieliryhmissä, juuri germaanissa on melko paljon sellaista sanastoaineista, joka viittaa kontakteihin kadonneiden kieliryhmien kanssa. Tätä hypoteesia tulisikin tutkia myös itämerensuomalaisten kielten germaanisten lainojen näkökulmasta. Kuinka suuri osa näistä sanoista on itse asiassa Itämeren piiriin rajoittuvia sanoja, jotka ovat sekä 
itämerensuomalaisessa että germaanisessa kielimuodossa uudennoksia ja joiden varhaisin alkuperä on molempia edeltäneissä kielissä?

\section{$7 \quad$ Lopuksi}

Ylläesitetyillä huomioilla toivon osoittaneeni, että vaikka etnohistorian tutkimus edistyy ja tarkentuu, on siinä nähtävissä enemmän jatkuvuutta kuin käänteitä. Langin "käänteentekevä" malli on aikaisempia malleja paremmin perusteltu, mutta sitä voi yhä kuvata jatkuvuusteoreettiseksi. Jatkuvuuden alkuvaihetta on tosin siirretty ja aluetta pienennetty. Kivikauden sijasta uralilainen kielellinen jatkuvuus ulottuu nyt vain pronssikaudesta nykyaikaan, eikä se enää koske Suomenlahden molempia rantoja vaan ainoastaan etelärantaa.

Malliin liittyy edelleen samoja ongelmia kuin muihinkin jatkuvuusteorian malleihin. Jos tarkastellaan tämän kirjoituksen aluksi esitettyjä jatkuvuusteorian ongelmia (kohdassa 1), on Langin teoria edelleen ongelmallinen sekä germaanikontaktien ajoituksen (1), itämerensuomalaisen areaalilingvistiikan (2) että tunnettujen kielialueiden analogioiden (4) suhteen. Saamelaissubstraattikysymys (3) näyttää sen sijaan nyt olevan ratkaistu, kun jatkuvuuden katsotaan koskevan vain Viroa eikä Suomea, jossa substraattia löytyy.

Lang pyrkii ratkaisemaan areaalilingvistiikka- ja germaanikontaktiongelmat olettamalla erillisiä uralilaistumisen aaltoja nyky-Viron alueella. Kielitieteilijä kysyy kuitenkin, mikä nyky-Viron alueella todistaa pronssikautisesta kielellisestä uralilaistumisesta? Mahdollinen todistusaineisto on lähinnä hiljaisuutta: Viron alueella ei ole jälkiä muunkielisestä substraatista ainakaan paikannimistössä, toisin kuin Suomessa. Alueen täytyy siis olla itämerensuomalaistunut paljon varhemmin kuin Suomen. Silti substraatin puute tarkoittaa myös sitä, että emme osaa sanoa (toistaiseksi?) juuri mitään Viron kielitilanteesta ennen alueen itämerensuomalaistumista, emmekä kielitieteen näkökulmasta myöskään itämerensuomalaistumisen kronologiasta. Vastaavia ongelmia liittyy Itämeren länsirannikon germaanistumiseen.

Kielitieteessä on viime vuosikymmeninä edistytty huomattavasti kielikontaktien sosiaalisen moninaisuuden ymmärtämisessä. Historiallista sosiolingvistiikkaa voi pitää jo vakiintuneena tutkimusalana. Seuraavan itämerensuomalaisen etnohistorian yleisesityksen kielellisenä lähtökohtana tulisikin nähdäkseni olla paitsi rekonstruoidut kantakielitasot, myös rekonstruoidut kontaktitilanteet (esim. Ross [1997] käyttää termiä speech community events).

Minkälainen on ollut esimerkiksi yhteisö, joka on omaksunut kantagermaanista sanastoa, ja mikä on ollut sen suhde germaaneihin? Vastaus on mahdollisesti, että kyseessä on ollut kulttuurinen "konglomeraatti", väestö joka on elänyt hyvin samalla tavoin kuin naapurinsa, mutta käyttänyt eri kieltä. Entä mikä tällaisessa tapauksessa voi olla arkeologisessa aineistossa havaittavissa oleva kielellisen erillisyyden korrelaatti? Vastauksen tähän kysymykseen joudun toistaiseksi jättämään auki. Tyydyn toteamaan, että kielen ja arkeologisen aineiston yhteensovittamisessa riittää edelleen ongelmia. 


\section{$8 \quad$ Kirjallisuus}

Aikio, Ante \& Aikio, Aslak 2001: Heimovaelluksista jatkuvuuteen. Suomalaisen väestöhistorian tutkimuksen pirstoutuminen. Muinaistutkija 4/2001. 2-21.

Aikio, Ante 2012: An essay on ethnolinguistic prehistory of the Saami. Kallio, Petri \& Grünthal, Riho: A linguistic map of prehistoric Northern Europe. Mémoires de la Société Finno-Ougrienne 266. 63-117.

Carpelan, Christian 2008: Arkeologia ja kielten historia. Halinen, P., Immonen, V., Lavento, M., Mikkola, T., Siiriäinen, A., \& Uino, P. (Eds.) (2008). Johdatus arkeologiaan. Helsinki: Gaudeamus Helsinki University Press. 313-324.

Carpelan, Christian \& Parpola, Asko 2002: Emergence, contacts and dispersal of Proto-Indo-European, Proto-Uralic and Proto-Aryan in an archaeological perspective. Christian Carpelan \& Asko Parpola \& Petteri Koskikallio (eds.): Early contacts between Uralic and Indo-European. Linguistic and archaeological considerations. Mémoires de la Société Finno-Ougrienne 242. 55-150.

Gosselain, Olivier 2000: Materializing identities. An African perspective. Journal of Archaeological method and theory 7. Springer. 187-217.

Grünthal, Riho 2018: Ein bedeutender Fortschritt in der Erforschung der Frühgeschichte des Ostseefinnischen. Finnisch-Ugrische Forschungen 64. 334-342.

Hackman, Alfred 1905: Die ältere Eisenzeit in Finnland I, Helsingfors 1905.

Horrocks, Geoffrey 2010: Greek: A history of the language and its speakers. Wiley Blackwell

Janhunen, Juha 2007: Uudet tuulet uralistiikassa. Tieteessä tapahtuu 2/2007. 56-59.

Janhunen, Juha 1997: Ethnicity and language in prehistoric Northeast Asia. In R. Blench \& M. Spriggs (Eds.), Archeology and language (Vol. 3). One World Archaeology (Vol. 34). London: Routledge

Haspelmath, Martin \& Tadmor, Uri 2009: Loanwords in the world's languages. A comparative handbook. De Gruyter Mouton.

Kallio, Petri 2007: Kantasuomen konsonanttihistoriaa. Jussi Ylikoski \& Ante Aikio (toim.): Sámit, sánit, sátnehámit. Riepmočála Pekka Sammallahtii miessemánu 21. beaivvi 2007. Mémoires de le Société Finno-Ougrienne 253. 229-249.

Kallio, Petri 2012: The Prehistoric Germanic Loanword Strata in Finnic. Petri Kallio \& Riho Grünthal: A Linguistic Map of Prehistoric Northern Europe. Mémoires de la Société Finno-Ougrienne 266. Helsinki: Société Finno-Ougrienne. 225-238.

Koivulehto, Jorma 1987: Namn som kan tolkas urgermanskt. Studier i nordisk filologi 67. 27-42.

Koivulehto, Jorma 2016: Die Urheimat der Germanen. Sampsa Holopainen \& Petri Kallio \& Janne Saarikivi: Verba vagantur. Jorma Koivulehto in memoriam. Mémoires de le Société Finno-Ougrienne 274. Helsinki: Société Finno-Ougrienne. 433-455.

Kroonen 2016: On the origins of the Elfdalian Elfdalian nasal vowels from the perspective of diachronic dialectology and Germanic etymology. Konferenssiesitys. Roots of Europe - Language, Culture, and Migrations Institute for Scandinavian Studies and Linguistics. (https://nors.ku.dk/ansatte/?pure=files/35220983/elfdalian.pdf).

Lang, Valter 2018: Läänemeresoome tulemised. Tartu: Tartu ülikooli kirjastus. 
Lang, Valter 2020: Homo fennicus. Itämerensuomalaisten etnohistoria. Helsinki: SKS.

Mallory, J. P. 1989: In search of the Indo-Europeans. Language, archaeology and myth. London: Thames \& Hudson.

Ringe, Donald A. 2006: From Proto-Indo-European to Proto-Germanic. Linguistic history of English 1. Oxford: Oxford University Press.

Ross, Malcolm 1997: Social networks and kind of speech-community event. Blench, Roger \& Spriggs, Mathew: Language and archaeology. One world archaeology 34. London - New York: Routledge.

Saarikivi, Janne \& Lavento, Mika 2012: Linguistics and Archaeology: A Critical View of an Interdisciplinary Approach with Reference to the Prehistory of Northern Scandinavia. Charlotte Damm \& Janne Saarikivi (eds.): Networks, Interaction and Emerging Identities in Fennoscandia and Beyond. Tromsø, Norway, October 13-16 2009. Mémoires de la Société Finno-Ougrienne 265. 177-216.

SVEJ = Suomen väestön esihistorialliset juuret. Bidrag till kännedom av Finlands natur och folk 131. Helsinki: Societas Scientiarum Fennica.

Terrell, John Edward 2001: Ethnolinguistic groups, language boundaries and culture history. A sociolinguistic model. - Terrell, John Edward (ed.): Archaeology, language and history. Essays on culture and ethnicity. Westport, Connecticut - London: Bergin \& Garvey

Wiik, Kalevi 2002: Eurooppalaisten juuret. Jyväskylä: Atena. 